\title{
KONSEP PERSAUDARAAN MENURUT ISLAM DAN BUDHA (SEBUAH STUDI KOMPARATIF)
}

\author{
Amalia Irfani
}

\begin{abstract}
Abstrak
Indahnya persaudaraan adalah bagian terpenting dari semua ajaran agamaagama. Islam yang universal dan Budha yang toleran adalah contoh bahwa agama sebagai perekat persatuan atas nama kebajikan/kebaikan di muka bumi. Kedua agama ini jelas berbeda, tidak akan pernah sama, sebab lahir dan berkembang dengan proses yang berbeda pula. Islam bersumber dari pemilik alam semesta terkondisikan melalui sebuah keyakinan/iman terucap dari syahadat. Sedangkan Budha juga mengklaim bahwa ajaran mereka adalah ajaran yang bersumber pada keyakinan pada satu wujud yang memiliki welas asih dan kebijaksanaan sebab adanya hubungan kausal. Keyakinan dalam buddhis, bercirikan: Membuka pandangan; meliputi keterbukaan dan keingintahuan dan Praktik; meliputi ritual (puja) dan pelaksanaan moralitas (sila) yang benar. Tulisan singkat ini akan sedikit menggambarkan tentang makna persaudaraan ajaran Islam dan ajaran Budha dalam studi komparatif; sebagai bagian memahami perbedaan dalam konsep kebhinekaan; dengan pesan semoga konflik yang terjadi dibelahan dunia atas nama agama mayoritas dan minoritas tidak lagi bertambah dan menjadi.
\end{abstract}

Kata Kunci: Persaudaraan, Islam dan Budha

\section{A. Pendahuluan}

Salah satu hal terpenting dalam kehidupan manusia di muka bumi adalah, terjalinnya persaudaraan yang kokoh dan harmonis. Tanpa persaudaraan, kehidupan manusia akan selalu diwarnai pertikaian, pertengkaran dan perpecahan. Mungkin tidak akan pernah ada senyum yang terlihat, yang ada hanya kemarahan dan dendam. Dalam wikipedia.com dijelaskan, sejarah organisasi persaudaraan pertama diketahui sudah ada sejak zaman Yunani Kuno dan dalam Misteri Mitraisme Romawi Kuno. Kemudian jika ada sebuah pertanyaan, mengapa persaudaraan itu cerminan kebahagiaan? Jawabannya tentu saja karena di dalam persaudaraan bernilai banyak hal, sebab ia terhubung karena pertalian hati dan dimensi spritual. Dalam kamus Bahasa Indonesia, Persaudaraan dari kata dasar 'saudara' yang artinya adik/kakak seayah dan seibu. Sedangkan arti persaudaraan adalah persahabatan yang sangat karib seperti layaknya saudara atau pertalian persahabatan yang serupa dengan pertalian saudara. Dengan kata lain, persaudaran adalah pertalian persahabatan yang sangat dekat 
bagaikan antara adik dan kakak seayah dan seibu. Kata persaudaraan dalam bahasa Arab biasa disebut dengan Ukhuwwah dan dalam bahasa Inggris disebut dengan Brotherhood. Islam mengajarkan bahwa persaudaraan atau ukhuwwah sangatlah penting dan mendapatkan porsi perhatian cukup signifikan. Oleh karena itu, Al-Qur'an dan Sunnah Nabi saw memberikan pesan dan menganjurkan agar sesama Muslim harus senantiasa menjaga persaudaran sesama mereka.

Mengutip pendapat Sayyid Qutb dalam Fii Zhilaalil Quran, iman itu memang ajaib. "Ketika telah meresap dalam hati, ia akan menjadikan hati itu dipenuhi rasa cinta dan kasih sayang di antara sesamanya. Yang keras beralih lunak, yang kasar menjelma lembut, yang kering berubah jadi basah, yang liar menjadi jinak. la-ia berjalin kelindan di antara sesamanya dengan jalinan yang kokoh, dalam, dan empuk. Tiba-tiba pandangan mata, sentuhan tangan, pembicaraan, gerak anggota badan, dan getar hati menjadi sebuah simfoni. Nyanyiannya merdu, diiringi saling pengertian, saling menyayangi, saling setia, tolong membantu, luasnya jiwa, dan sikap lapang dada. Tak ada yang mengetahui kegaiban himpunan hati ini, kecuali Dia yang telah mempersatukannya. Tak ada yang merasakan indahnya kecuali hati-hati itu sendiri. Mereka berikrar untuk bermesra di jalan-Nya.

Pendapat Sayyid Qutb, menjelaskan arti sesungguhnya persaudaraan. Dalam konsep Islam Persaudaraan adalah tali. Saling menjaga dalam kebaikan, saling menguatkan ketika yang lain lemah, saling menasehati, saling menyayangi, saling mengasihi dan saling mencintai. Sebagaimana sabda Rasulullah "seorang mukmin bagi mukmin lainnya laksana bangunan, satu sama lain saling menguatkan" (Muttafaq llaih). Maka "Persaudaraan adalah mukjizat, wadah yang saling berikatan dengannya Allah persatukan hati-hati berserakan. Saling bersaudara, saling merendah lagi memahami, saling mencintai, dan saling berlembut hati"

Jika konsep Islam tentang persaudaraan begitu tinggi, pada ajaran agama lain pun, persaudaraan di pandang sebagai kekuatan dari struktur agama. Agama Budha misalnya, sebagai agama besar di dunia, memandang bahwa persaudaraan merupakan bentuk lain menghilangkan kemungkaran. Siddharta Gautama sang Budha menegaskan kehidupan bisa baik dan abadi salah satunya melalui persaudaraan.

Menarik untuk dikaji; dalam tulisan ini penulis akan sedikit menelisik perbedaan konsep persaudaraan antara kedua agama yang masing-masing 
dengan cirinya masing-masing. Jika persaudaraan diamini sebagai sebuah bagian terdalam dari agama, maka manifestasinya adalah kedamaian bukan kebalikannya. Dipilihnya Islam dan Budha sebagai bahan konsep diskusi dalam tulisan ini, sebab dalam beberapa waktu terakhir Islam dan Budha menjadi agama perbincangan dunia. Islam yang mayoritas di Indonesia berhasil menyedot perhatian dunia dengan aksi damai 212nya; bahkan mungkin memunculkan anggapan lain selain hanya sebuah aksi. Sedangkan Myanmar dengan mayoritas Budha malah kebalikannya, aksi berdarah dan pembunuhan massal. Beberapa media bahkan menyebut aksi yang dilakukan di Myanmar adalah genosida yang sengaja dilancarkan karena muatan agama. Wallahualam

\section{B. Persaudaraan dalam Islam dan} Ajaran Budha

\section{Persaudaraan dalam Islam}

Manusia pada hakikatnya adalah umat yang satu. Kemudian Allah mengutus para nabi sebagai pemberi kabar gembira dan pemberi peringatan. (Q.S. Al-Baqarah [2]: 213)

Ayat di atas merupakan penjelasan kepada tentang tujuan diutusnya para nabi, yakni untuk memberikan kabar gembira dan memberi peringatan kepada semua ummat. Kabar gembira bagi orang yang mau tunduk dan taat menjalankan perintah-perintah Allah, mereka akan memperoleh kebahagiaan di dunia dan akhirat. Peringatan kepada orang yang tidak mau patuh kepada perintah Allah dan gemar berbuat kejahatan dan kerusakan di muka bumi, mereka akan mendapatkan siksa kelak di akhirat. Al-Qurthubi dalam kitabnya, alJami' li al-Ahkam al-Qur'an, mengatakan bahwa ayat al-Qur'an di atas merupakan peringatan kepada kita untuk senantiasa mengingat kembali asal-usul kita. Terutama jika menghadapi konflik atau pertikaian, hendaklah kita membuka nurani dengan mengingat kembali pada asal mula kita. Manusia pada hakikatnya adalah umat yang satu, yakni sama-sama sebagai keturunan Adam. Begitu dalamnya pernyataan Qurthubi, seolaholah meyakinkan kita bahwa, sebagai manusia kita sama-sama diciptakan Allah dari tanah, dan kelak jika meninggal kita akan dikubur ke dalam tanah (juga).

Dengan pandangan ini, perbedaan yang ada bukan menjadi masalah, tapi sebaliknya merupakan rahmat yang dikaruniakan Allah. Inilah ajaran universal yang ditawarkan oleh Islam. Ajaran untuk berpegang teguh kepada persaudaraan antar sesama manusia, atau yang dikenal dengan ukhuwah basyariyah. Rasulullah SAW ketika memulai dakwahnya di Madinah membuat piagam kesepakatan yang dikenal dengan Piagam Madinah. Di dalam piagam tersebut, Rasulullah 
menegaskan kalimat sebagaimana kalimat dalam ayat di atas, "Manusia pada hakikatnya adalah umat yang satu." Dengan pengakuan diri sebagai saudara bagi manusia lain, berarti telah menganggap orang lain menjadi bagian dari diri kita. Karena semua bersaudara, berarti didak ada istilah musuh di sini. Karena merasa sebagai umat yang satu, semua kasih sayang yang kita curahkan juga untuk semua manusia.

\section{Ukhuwah basyariyah bukan}

hanya sebatas penghormatan kepada sesama manusia. Juga bukan sebatas sikap tidak mau mengganggu orang lain. Namun tindakan aktif yang merupakan panggilan jiwa untuk menjunjung harkat dan martabat kemanusiaan. Jiwa kita akan terpanggil untuk memberi makan bagi mereka yang lapar dan menolong yang terkena musibah. Bersedia meringankan beban penderitaan orang lain dengan atau tanpa dimintai pertolongan. Dan yang lebih penting lagi adalah menciptakan kehidupan yang damai. Sebab pertikaian atau peperangan seringkali mengorbankan kemanusiaan itu sendiri.

Secara sosiologis, dalam konsep Islam persaudaraan dapat dibagi menjadi empat macam. Pertama Persaudaraan Islam atau Ukhuwah Islamiyah. Kedua, Persaudaraan Keluarga atau AlUkhuwwah An-Nasaliyyah. Ketiga Persaudaraan sesama manusia atau AlUkhuwwah

Al-Basyariyyah.
Persaudaraan dalam Islam tercermin jelas seperti yang dibawa oleh para Nabi kepada Ummat manusia.

\section{a). Persaudaraan Islam (Ukhuwah Islamiyah)}

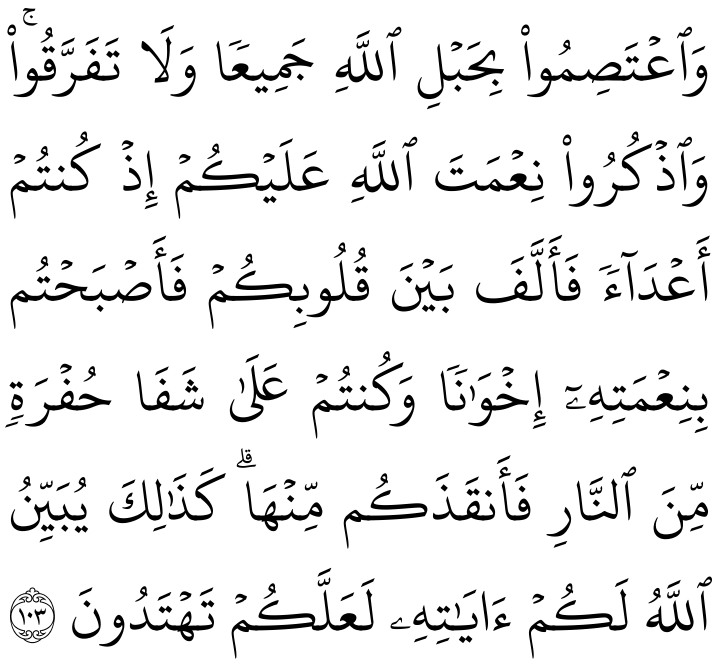

Artinya:

Dalam Islam telah dikenal adanya Persaudaraan Islamiyyah atau AlUkhuwwah Al-Islamiyyah. Hal ini didasarkan pada ajaran Islam yang bersumber dari Al-Qur'an dan Sunnah Nabi saw. Diantara firman Allah yang menjelaskan tentang masalah persaudaraan adalah : "Dan perpeganglah kamu semuanya kepada tali (agama) Allah, dan janganlah kamu bercerai-berai, dan ingatlah akan nikmat Allah kepadamu ketika kamu dahulu (masa jahiliyah) bermusuh-musuhan, maka Allah mempersatukan hatimu, lalu menjadikan kamu karena nikmat Allah menjadi bersaudara; dan kamu telah berada di tepi jurang neraka, lalu Allah menyelamatkan kamu dari padanya." (Ali Imran: 103).

Ukhuwah atau persaudaraan dalam Islam bukan saja mencirikan kualitas ketaatan seseorang terhadap ajaran Allah dan Rasul-Nya, tetapi juga sekaligus merupakan salah satu kekuatan 
perekat sosial untuk memperkokoh kebersamaan. Fenomena kebersamaan ini dalam banyak hal dapat memberikan inspirasi solidaritas sehingga tidak ada lagi jurang yang dapat memisahkan silaturahmi di antara umat manusia sebagai mahluk sosial yang dianugrahi kesempurnaan. Meskipun demikian, dalam perjalanan sejarahnya, bangunan kebersamaan ini seringkali terganggu oleh godaan-godaan kepentingan yang dapat merusak keutuhan komunikasi dan bahkan mengundang sikap dan prilaku yang saling berseberangan. Karena itu, semangat ukhuwah ini secara sederhana dapat terlihat dari ada atau tidak adanya sikap saling memahami untuk menumbuhkan interaksi dan komunikasi.

Ukhuwah Islamiyah sendiri menunjukkan jalan yang dapat ditempuh untuk membangun komunikasi di satu sisi, dan di sisi lain, ia juga memberikan semangat baru untuk sekaligus melaksanakan ajaran sesuai dengan petunjuk al-Qur'an serta teladan dari para Nabi dan Rasul-Nya. Sekurangsekurangnya ada dua pernyataan Nabi SAW, yang menggambarkan persaudaraan yang Islami. Pertama, persaudaraan Islam itu mengisyaratkan wujud tertentu yang dipersonifikasikan ke dalam sosok jasad yang utuh, yang apabila salah satu dari anggota badan itu sakit, maka anggota lainnya pun turut merasakan sakit. Kedua, persaudaraan Islam itu juga mengilustrasikan wujud bangunan yang kuat, yang antara masing-masing unsur dalam bangunan tersebut saling memberikan fungsi untuk memperkuat dan memperkokoh. Ilustrasi pertama menunjukkan pentingnya unsur solidaritas dan kepedulian dalam upaya merakit bangunan ukhuwah menurut pandangan Islam. Sebab Islam menempatkan setiap individu dalam posisi yang sama. Masing-masing memiliki kelebihan, lengkap dengan segala kekurangannya. Sehingga untuk menciptakan wujud yang utuh, diperlukan kebersamaan untuk dapat saling melengkapi. Sedangkan ilustrasi berikutnya menunjukkan adanya faktor usaha saling tolong menolong, saling menjaga, saling membela dan saling melindungi.

Pernyataan al-Qur'an: Innama al-mu'minuuna ikhwatun (sesungguhnya orang-orang mu'min itu bersaudara) memberikan kesan bahwa orang mu'min itu memang mestinya bersaudara. Sehingga jika sewaktu-waktu ditemukan kenyataan yang tidak bersaudara, atau adanya usaha-usaha untuk merusak persaudaraan, atau bahkan mungkin adanya suasana yang membuat orang enggan bersaudara, maka ia berarti bukan lagi seorang mu'min. sebab penggunaan kata "innama" dalam bahasa Arab menunjukkan pada pengertian "hany saja". Tuntutan normatif seperti tertuang dalam al-Qur'an di atas memang seringkali tidak menunjukkan kenyataan 
yang diinginkan. Kesenjangan ini terjadi, antara lain, sebagai akibat dari semakin memudarnya penghayatan terhadap pesan-pesan Tuhan khususnya berkaitan dengan tuntutan membina persaudaraan.

\section{b). Persaudaraan Keluarga}

Dalam sejarah kehidupan umat manusia, perselisihan dan pertengkaran dalam keluarga sering kali terjadi, dengan berbagai sebab. Misalnya karena faktor kecemburuan dan ketidakadilan, baik dalam masalah harta, seperti warisan maupun masalah lainnya. Mungkin kita masih ingat, pembunuhan yang dilakukan oleh Qabil terhadap habil atau kakak terhadap adiknya.

Untuk menjaga hubungan persaudaraan dalam keluarga, Nabi Muhammad saw telah mengajarkan kepada kita dengan sabda nya: "Shadaqah terhadap orang miskin hanya mendapat pahala shadaqah, sedangkan terhadap kerabat (keluarga) mempunyai dua pahala yaitu pahala shadaqah dan pahala shilah (persaudaraan)." (HR At-Turmudzi). Dan Allah swt juga menegaskan dalam firmannya bahwa diantara kebajikan itu adalah memberikan harta yang dicintainya kepada kerabat (saudaranya). (QS Al-Baqarah 177). Disisi lain Nabi saw juga memberikan penegasan dan sekaligus ancaman bagi orang yang memutuskan tali persaudaraan dengan sabdanya: "Tidak akan masuk surga seorang pemutus tali silaturrahmi (persaudaraan)." (HR. Bukhari Muslim)

\section{c). Persaudaraan Sebangsa}

Ketika Nabi saw dan para sahabatnya hijrah ke Madinah, maka dibentuklah pemerintahan Islam pertama dan Nabi sebagai pemimpin. Untuk mengatur jalannya roda pemerintahan, dibuatlah atauran atau undang-undang sedemikian rupa, diantaranya undangundang yang mengatur kehidupan masyarakatnya. Salah satunya adalah peraturan mengenai hubungan masyarakat minoritas non muslim dengan masyarakat muslim ataupun sebaliknya. Diantara aturan itu adalah masyarakat mayoritas (muslim) tidak boleh melakukan tindakan sewenang-wenang terhadap kaum minoritas non muslim. Bahkan Nabi saw berpesan melalui haditsnya: "Barang siapa yang menyakiti orang (kafir) dzimmi, maka ia telah menyakitiku." (Al-Hadits). Dari kutipan hadits di atas kita bisa memahami bahwa Nabi saw memberikan jaminan keselamatan kaum minoritas. Ini merupakan gambaran sekilas bentuk persaudaraan sebangsa dan setanah air yang tumbuh pada dunia Islam.

\section{Persaudaraan dalam Ajaran Budha}

Dalam agama Budha, persaudaraan digambarkan sebagai cinta kasih dan norma kehidupan. Pengembangan cinta kasih atau Mettã 
adalah

rasa

persaudaraan,

persahabatan, pengorbanan, yang mendorong kemauan baik, memandang makhluk lain sama dengan dirinya sendiri (Dhammasugiri, 2004: 21). Hal tersebut mencerminkan bahwa dengan melaksanakan cinta kasih maka akan dapat tercipta keharmonisan. Seseorang yang mengembangkan cinta kasih berarti mempraktikkan prinsip tanpa kekerasan, maka timbullah persaudaraan.

Inti dari ajaran Budha, menjelaskan bahwa Kejahatan adalah sumber adanya ketidakharmonisan. MettÄ $\square$ adalah satu-satunya jawaban efektif bagi kekerasan dan penghancuran, baik dari senjata konvensional maupun peluru nuklir (Bogoda, 2003: 70). Seperti yang dialami Buddha sendiri ketika sedang bermeditasi kemudian diganggu oleh mara, dengan kekuatan cinta kasih panah dan lautan api tidak bisa melukai Buddha. Berdasarkan Å̊, guttara NikÄya (Hare, 2001: 103) manfaat dari mengembangkan cinta kasih adalah tidak ada api, racun, maupun pedang yang dapat melukainya. Cinta kasih merupakan kekuatan dari dalam diri seseorang sebagai pencegah perbuatan buruk. Pengembangan cinta kasih bertujuan untuk memisahkan pikiran dari kebencian. Prinsip dari cinta kasih adalah tidak menyakiti, bebas dari rasa benci, dan permusuhan.

Sesuai dengan macam-macam cinta yang dikemukakan oleh Davids
(1915: 159-162) yaitu adanya cinta keluarga dan saudara. Keharmonisan hendaknya tercipta sejak dalam lingkup keluarga. Hubungan antar anggota keluarga seharusnya didasari oleh cinta kasih. Setelah mengembangkan cinta kasih kepada keluarga, maka cinta kasih dikembangkan kepada sahabat atau teman. Keharmonisan akan terwujud dalam hubungan sahabat. Keharmonisan dapat terwujud dengan adanya cinta kasih karena cinta kasih dirumuskan sebagai keinginan akan kebahagian semua makhluk tanpa kecuali. Setelah mengetahui manfaat dari cinta kasih maka akan dapat diketahui bahwa cinta kasih dapat membawa keharmonisan di masyarakat. Pengembangan cinta kasih terdapat unsur menghormati dan kepedulian kepada yang lain. Adanya saling menghormati dan saling peduli akan tercipta keharmonisan. Cinta kasih atau $m e t t \ddot{A} \square$ sering dikatakan sebagai keinginan suci yang mengharapkan kesejahteraan dan kebahagiaan makhluk-makhluk lain, seperti seorang sahabat mengharapkan kesejahteraan dan kebahagiaan temannya (Wowor, 2005: 76). Adanya keinginan atau niat seseorang untuk kesejahteraan dan kebahagiaanorang lain maka akan menciptakan keharmonisan.

MettÄ $\square$ menambah kemurahan hati pada sifat seseorang, memberikan keakraban, membebaskan diri dari kejengkelan dan selalu menimbulkan 
kegembiraan, keramah-tamahan serta tidak ada rasa permusuhan atau keinginan untuk menyakiti makhluk lain bahkan terhadap makhluk yang paling kecil sekalipun, yang biasanya disebabkan karena kebencian, kemarahan atau hanya karena iseng (Ñanasamvara, 2001: 15). Kebencian adalah lawan dari cinta kasih. Apabila dalam hubungan antara satu dengan yang lain tidak terdapat kebencian dan permusuhan maka dapat tercipta keharmonisan dan kedamaian dalam suatu masyarakat. Cinta kasih dapat menciptakan keharmonisan. Perasaan cinta kasih yang dimiliki oleh seorang ibu misalnya bukan cinta yang didasarkan atas nafsu untuk memiliki, tetapi keinginan yang murni untuk menyejahterakan dan membahagiakan anaknya. Pengembangan cinta kasih yang dimiliki seorang ibu kepada anaknya yang tunggal adalah yang diharapkan dalam pengembangan cinta kasih kepada semua makhluk, yaitu pengembangan cinta kasih yang terwujud dalam keinginan sepenuh hati untuk menyejahterakan dan membahagiakan semua makhluk tanpa kecuali, dan cinta kasih dipancarkan ke segala penjuru, begitu pula ke atas, ke bawah, ke sekeliling, ke semua arah.

MettÄ $\square$ juga adalah adalah niat baik, cinta kasih, cinta universal; suatu perasaan persahabatan dan perhatian tulus terhadap semua makhluk hidup, manusia atau bukan manusia dalam segala situasi. Tanda utama $m e t t \ddot{A} \square$ adalah niat baik: keinginan kuat untuk meningkatkan kesejahteraan orang $\quad$ lain. MettÄ $\square$ menundukkan kebencian dalam segala bayangannya: kemarahan, niat buruk, keengganan, dan dendam. Tidak adanya kemarahan, niat buruk, dan dendam maka kerukunan dan keharmonisan dalam masyarakat akan tercipta.

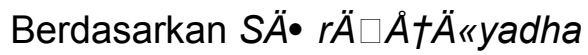
mma Sutta, $A \AA \AA$,guttara Nik $\ddot{A} \square$ ya (Hare, 2001: 203) Buddha mengatakan kepada para bhikkhu bahwa apabila seseorang memiliki perbuatan, ucapan, dan pikiran yang disertai cinta kasih terhadap sesama, baik di depan atau pun di belakangnya. Hal tersebut yang membuat saling dikenang, dicintai, saling dihormati, dan menunjang untuk saling ditolong, untuk ketiada-cekcokan, kerukunan, dan kesatuan. Apabila seseorang memiliki cinta kasih tidak akan mungkin menyakiti orang lain, karena prinsip dari pengembangan cinta kasih adalah mengharapkan makhluk lain bahagia. Seseorang akan menolong, membantu, dan membuat orang lain bahagia. Menolong orang lain merupakan praktik cinta kasih, karena cinta kasih adalah sesuatu kekuatan aktif. Setiap tindakan mencintai yang dilakukan dengan pikiran tak bernoda untuk menolong, membantu, menyenangkan, membuat jalan orang lain mudah, lebih halus, dan lebih sesuai 
penaklukan kesedihan, adalah kebahagiaan tertinggi (Dhammananda, 2004: 242). Membahagiakan orang lain, maka seseorang akan merasa bahagia, karena orang yang melakukan perbuatan baik akan mendapatkan akibat yang baik, sedangkan orang yang melakukan kejahatan akan menuai hasil dari perbuatan jahat. Berdasarkan Kitab Dhammapada, Khuddaka NikÄ $\square$ ya (Norman, 2004: 19) dijelaskan bahwa: "Not in the sky, not in the middle of the sea, not entering an opening in the mountains is there that place on earth where standing one might be freed from evil action."Seseorang akan mendapatkan akibat dari segala sesuatu yang telah dilakukan baik atau pun buruk. Pembuat kebajikan akan mendapatkan kebaikan, pembuat kejahatan akan mendapatkan kejahatan. Seseorang tidak dapat mengingkari sebuah akibat dari perbuatannya.

\section{Persaudaraan dalam Islam dan}

\section{Ajaran Budha (Komparatif)}

Dari penjelasan diatas, dapat kita simpulkan bahwa Islam dan Budha memiliki pemaknaan berbeda tentang persaudaraan. Walaupun sama-sama bernilai baik atau positif; intisari dari ajaran yang berlandaskan Ketuhanan dan Kemanusiaan jelas tidak sama. Islam secara tegas memandang persaudaraan adalah salah satu aspek yang vital dan sangat ditekankan di dalam ajaran agama
Islam. Begitu banyak anjuran dan perintah yang menyerukan untuk mengeratkan ikatan persaudaraan antar sesama umat Islam, dan banyak pula larangan untuk memutuskan tali persaudaraan di dalam Islam. Semua itu telah disampaikan di dalam ajaran agama Islam, baik melalui firman Allah swt di dalam Al Quran maupun melalui sabda Rasulullah saw di dalam Al Hadits. Rasulullah sendiri yang merupakan seorang manusia pilihan telah menunjukkan bagaimana seharusnya umat Islam senantiasa menjaga hubungan persaudaraannya. Melalui sabdanya, beliau telah begitu banyak mengingatkan kepada umatnya untuk senantiasa menjaga keutuhan persaudaraanya di dalam Islam, karena Islam adalah agama yang mengharamkan umatnya untuk memutuskan tali persaudaraan atau silaturahmi, terutama dengan saudara yang berada dalam satu naungan agama Islam.

Mempererat persaudaraan Islam juga merupakan salah satu bentuk penegakan power Islam dalam kehidupan sehari-hari. Karena umat Islam yang satu dengan yang lain itu ibarat sebuah bangunan yang saling melengkapi dan saling menguatkan. Jika ada kekurangan dari saudaranya, maka sudah menjadi kewajibannyalah untuk senantiasa melengkapi atau menjaganya, bukan justru membuang atau memutuskannya. 
Umat muslim yang satu dengan yang lain ibarat satu tubuh yang jika salah satu anggota badannya mengalami sakit, maka seluruh tubuh akan merasakannya pula. Di sinilah kekuatan Islam akan terbentuk melalui sebuah hubungan persaudaraan yang kuat. Gerakan 212 di Indonesia 2016-2017 dan aksi solidaritas Palestina adalah bukti konkrit betapa kuatnya persaudaraan dalam Islam dalam satu aqidah dan iman.

Sedangkan dalam ajaran Budha, posisi persaudaraan adalah bagian dari kebahagiaan hidup. Cinta kasih atau persaudaraan adalah keinginan akan kebahagiaan semua makhluk tanpa kecuali, yang sering dikatakan sebagai niat suci untuk mengharapkan kesejahteraan dan kebahagiaan makhluk lain. Cinta kasih merupakan sebuah kekuatan yang tidak hanya membawa kebahagiaan kepada para pelakunya, tetapi juga untuk para makhluk di sekitarnya. Hal tersebut dapat terjadi karena pengembangan cinta kasih ditujukan kepada semua makhluk tanpa kecuali. Sedangkan objek pengembangan cinta kasih yaitu: pertama kali cinta kasih dipancarkan kepada diri sendiri, setelah itu cinta kasih dipancarkan kepada orang-orang yang dihargai dan dicintai, orang netral, dan musuh. Pengembangan cinta kasih pertama kali harus ditujukan kepada diri sendiri, karena untuk dapat mengembangkan cinta kasih kepada orang lain atau makhluk lain harus memiliki cinta kasih kepada diri sendiri terlebih dahulu.

Ajaran cinta kasih memiliki posisi yang amat penting dalam agama Buddha. Cinta kasih apabila dikembangkan dengan baik, maka akan menciptakan keharmonisan di alam semesta, yaitu keharmonisan antara manusia dengan binatang, binatang dengan tumbuhan, tumbuhan dengan manusia, atau bahkan keharmonisan antara makhluk satu dengan makhluk yang lain, misalnya makhluk yang tidak tampak (setan, dewa). Hal tersebut dikarenakan cinta kasih dipancarkan tidak hanya kepada sesama manusia tetapi kepada semua makhluk yang ada di alam semesta. Semua penghuni alam semesta saling membutuhkan dalam menjalani kehidupannya, sehingga cinta kasih sangat diperlukan. Selain sebagai landasan keharmonisan, cinta kasih dapat berfungsi sebagai landasan kemajuan batin. Cinta kasih merupakan salah satu objek meditasi. Melalui meditasi seseorang dapat membebaskan kebencian dalam batin, sedangkan kebencian adalah salah satu akar dari kejahatan. Jika seseorang membebaskan kebencian dari batinnya, maka batinnya telah mengalami kemajuan. Dengan adanya kebebasan pikiran cinta kasih dapat membawa seseorang mencapai tingkat kesucian $A n \ddot{A} \square g \ddot{A} \square m i$ dan merupakan latihan tahap awal yang 
dilaksanakan manusia untuk mencapai kebahagiaan tertinggi (nibbÄ $\square$ na).

\section{Kesimpulan}

Dari uraian diatas, dapat disimpulkan bahwa Persaudaraan merupakan bagian terpenting dalam kehidupan manusia. Persaudaraan memunculkan semangat dan motivasi positif, walaupun kenyataannya tidak selalu atas nama persaudaraan kehidupan manusia akan berjalan teratur, baik dan harmonis. Sebagai agama besar dunia, Islam dan Budha memiliki keunikan ajaran tersendiri, diyakini oleh pemeluknya atas dasar iman. Ajaran Islam yang universal dan ajaran Budha yang toleran adalah bentuk baku yang tidak mungkin disamakan.

Persaudaraan dalam Islam adalah seni keindahan hidup, ajaran Budha pun meyakini hal yang sama. Persaudaraan dalam Islam menunjukkan jalan yang dapat ditempuh untuk membangun komunikasi di satu sisi, dan di sisi lain, ia juga memberikan semangat baru untuk sekaligus melaksanakan ajaran sesuai dengan petunjuk al-Qur'an serta teladan dari para Nabi dan Rasul-Nya. Sekurangsekurangnya ada dua pernyataan Nabi SAW, yang menggambarkan persaudaraan yang Islami. Pertama, persaudaraan Islam itu mengisyaratkan wujud tertentu yang dipersonifikasikan ke dalam sosok jasad yang utuh, yang apabila salah satu dari anggota badan itu sakit, maka anggota lainnya pun turut merasakan sakit. Kedua, persaudaraan Islam itu juga mengilustrasikan wujud bangunan yang kuat, yang antara masing-masing unsur dalam bangunan tersebut saling memberikan fungsi untuk memperkuat dan memperkokoh. Ilustrasi pertama menunjukkan pentingnya unsur solidaritas dan kepedulian dalam upaya merakit bangunan ukhuwah menurut pandangan Islam. Sebab Islam menempatkan setiap individu dalam posisi yang sama.

Ajaran Budha, persaudaraan digambarkan sebagai cinta kasih dan norma kehidupan. Pengembangan cinta kasih atau Mettã adalah rasa persaudaraan, persahabatan, pengorbanan, yang mendorong kemauan baik, memandang makhluk lain sama dengan dirinya sendiri Seseorang yang mengembangkan cinta kasih berarti mempraktikkan prinsip tanpa kekerasan, maka timbullah persaudaraan. Posisi persaudaraan dalam ajaran Budha adalah bagian dari kebahagiaan hidup. Cinta kasih atau persaudaraan adalah keinginan akan kebahagiaan semua makhluk tanpa kecuali, yang sering dikatakan sebagai niat suci untuk mengharapkan kesejahteraan dan kebahagiaan makhluk lain. 


\section{Daftar Pustaka}

Bogoda, Robert. Tanpa Tahun. Hidup Sederhana Hidup Bahagia. Terjemahan oleh Ida Dhammashanti. 2003. Jakarta: Yayasan Penerbit Karaniya.

Davids, T.W Rhys. (Ed). 1972. PÄ $\square$ liEnglish Dictionary. London: The Pali Text Society.

Depag. R.I., Al-Qur'an dan Terjemahnya, Depag R.I.: Proyek Pengadaan Kitab Suci Al Qur'an, 2000.

https://islami.co/konsep-persaudaraanumat-manusia-dalam-islam/

Shihab, M. Quraisy, 2007. Wawasan AlQur'an, Bandung: PT. Mizan Pustaka

Waryono Abdul Ghafur. 2016.

Persaudaraan Agama-Agama,

Bandung: PT. Mizan Pustaka

Wikipedia.com 